\title{
The Soft Power Currencies of US Navy Hospital Ship Missions ${ }^{1}$
}

\author{
LARISSA FORSTER \\ University of Michigan
}

\begin{abstract}
The Tsunami in South-East Asia in 2004 prompted the largest military disaster response in history. Encouraged by the success, increasing attention has been paid to the various humanitarian assistance and disaster relief activities conducted by US armed forces. Since 2006, the US Navy deploys one of its two large hospital ships in annual missions to either Central and South America or the Asia-Pacific region to provide people in need with free care. These missions offer many opportunities to increase the soft power capital of the United States by forging ties with host nation governments and improving the image of the United States within the local population. However, this article argues that we need more research on the impact of humanitarian assistance to justify a continuation in a fiscally constrained environment.
\end{abstract}

Keywords: humanitarian assistance, soft power, US Navy, hospital ship, health diplomacy

\begin{abstract}
What better way to knock down the hatred, the barriers of ethnic and religious groups that are afraid of America, and hate America, than to offer good medical policy and good health to these countries?

(Thompson 2004)
\end{abstract}

The newest maritime strategy "A Cooperative Strategy for 21st Century Seapower" (United States Navy, Marine Corps, and Coast Guard 2007) lists humanitarian assistance (HA) and disaster relief (DR) among the core competencies of US maritime forces. While in prior years, these tasks were treated as an "extra," they now have been promoted to being equally as important as the four traditional naval missions of sea control, presence, deterrence, and power projection. The US military has a long tradition of providing humanitarian aid. During World War I, for example, President Wilson used food as a form of disaster relief to counter the spread of Bolshevism and civil unrest (Zajtchuck 2003). A Center for Naval Analyses (Cobble, Gaffney, and Gorenburg 2005) study on US military responses to international situations between 1970 and 2003 identified only 22 combat operations compared with $366 \mathrm{HA} / \mathrm{DR}$ missions. These numbers clearly show the importance and frequency of HA and DR, yet little has been written about the role and experience of military forces in these domains. While the traditional naval missions advance US interest, the contribution of HA/DR is still contested and needs to be evaluated. This article aims to contribute to the important debate regarding the usefulness of military forces in the humanitarian

\footnotetext{
${ }^{1}$ I am pleased to acknowledge the help of Lynn Alberding, Robert Axelrod, Ivo Dobrev, Theresa Jackson, Katherine Lacasse, Solomon Major, and Albert Shimkus.

[Corrections added 27 February 2015, after original online publication: grammatical changes have been made to this article to improve clarity.]
} 
arena by exploring the soft power potential of naval humanitarian assistance. With the unprecedented use of military assets during the Tsunami 2004 relief efforts, a new level of military involvement had been reached and continues to affect all future humanitarian operations. The often-cited success of US aid provided the impetus for more regular, scheduled, proactive humanitarian medical missions with US naval hospital ships as a platform. The goals of this paper are twofold. First, it places hospital ship missions in the context of the concept of soft power. Second, it identifies important areas of research to better understand the benefits of these missions.

\section{Defining the Concepts}

\section{Hard Power and Soft Power: Coercion Versus Attraction}

The term "soft power" was coined by Joseph Nye in Bound to Lead (1990) who offers the following definition: "soft power is the ability to affect others through the cooptive means of framing the agenda, persuading, and eliciting positive attraction in order to obtain preferred outcomes" (Nye 2011). Unlike hard power, which influences through coercion, soft power exerts a subtle influence. According to Nye $(2004,2011)$, the goal is to get others to want what you want without coercing them. Vuving (2009) suggests instead that getting others to accept what you want can be enough. After the terrorist attacks of $9 / 11$, the United States had pursued a unilateral foreign policy and relied heavily on military means to resolve all security problems (Feste 2003; Nye 2011). The preemption doctrine had removed any distinction between imminent and potential future threats. It assumed that grave threats were now always imminent. This thought process led to the devaluation of diplomacy and negotiation and shifted the emphasis to the use of immediate force, thereby failing to distinguish between short- and long-term threats and different adversaries. After many years of neglecting soft power approaches, a policy shift became visible with the release of the National Security Strategy (NSS) 2010 and the Quadrennial Defense Report (QDR) 2010. Both strategic documents emphasized the renewed US interest to invest in soft power. "As a global power, the United States has a broad range of tools for advancing its national interests (...). Whenever possible, we seek to pursue those interests through cooperation, diplomacy, economic development and engagement, and the power of America's ideas and values" (QDR 2010).

Nye (2011) argues that while hard power is and will remain important, it is not sufficient. Power has different aspects and faces (Dahl 1961). The first face ${ }^{2}$ uses coercion or incentives to reach the desired outcome. The second face controls actions to limit possible choices. The third face-soft power-creates and shapes beliefs, perceptions, and preferences. Only the first face of power is directly felt, the two other faces exert a more subtle influence on their target but are allegedly nevertheless effective. More recently, Nye (2004) defined the combination of the hard power of coercion and payment with the soft power of persuasion and attraction as "smart power." With their capability to exercise both soft and hard power, naval forces are a unique smart power tool. This is also reflected in the newest naval strategy (United States Navy, Marine Corps, and Coast Guard 2007). According to Elleman (2007, quoted in United States Navy 2010), "during the nineteenth and most of the twentieth centuries, the very thought that sea powers might regularly use naval platforms to deliver humanitarian aid, as opposed to cutting off and starving an enemy's supply lines, would

\footnotetext{
${ }^{2}$ Incentives can come in the form of payments or inducements. Another form is negative sanctions, for example, taking away economic assistance previously provided.
} 
have seemed alien. In the twenty-first century, however, national power and prestige are more and more characterized by soft power. UNIFIED ASSISTANCE [after the Tsunami in South-East Asia] showed that hard power assets like aircraft carriers can also be the best providers of soft power."

Soft power has also attracted much criticism. Joffe (2006) cautions that soft power is still a form of power and "does not necessarily increase the world's love for America." And like all forms of power, it can still create enemies. Another weakness of soft power is that it lies within the people to decide how much power it will have, and there is little to no control how the actions will be perceived by the target population. Gray (2011:vi-viii) argues that "an important inherent weakness of soft power as an instrument of policy is that it utterly depends upon the uncoerced choices of foreigners. Sometimes their preferences will be compatible with ours, but scarcely less often they will not be." In general, the concepts of attraction and persuasion and their translation into soft power are difficult to measure. But when trying to convince others to pursue soft power approaches, it is important to be able to demonstrate their effectiveness.

\section{Peacetime Deployments of Naval Forces}

The US Navy (USN) has been the predominant military instrument of diplomacy, due largely to its greater mobility and flexibility compared to the other services (Turner 1974; Till 2009). Army and Air Force are more likely associated with greater threat and destruction. Naval forces are less intrusive and offer a more subtle influence. This offers unique opportunities to create soft power. The diplomatic potential of navies has long been recognized by nations and can be traced back to the heritage of colonial powers that would dispatch their fleets to boost their prestige and to influence events ashore (Davidson 2009). While some argue that the use of coercive diplomacy is a thing of the past, others see an increasing need in an era in which the focus of the USN is shifting away from large-scale conflicts (Nailor 1984; Booth 1985; Ghosh 2001; Le Mière 2011).

Naval diplomacy acts as a signal demonstrating US interest and concern in particular regions and countries. Any naval deployment demonstrates US commitment and capabilities (Sanders 2007). At the lower end of the diplomatic spectrum are measures such as goodwill visits, exercises, and other confidencebuilding activities. At the higher end, armed suasion is the most forceful aspect of coercive diplomacy (Stocker 1998). Further traditional diplomatic peacetime activities center on cooperation and exercises, military-to-military contacts, officer training, and access agreements as means of demonstrating and building positive relationships. Even daily activities such as "ship visits can be a useful form of diplomatic exchange, help maintain or secure good relations, and win popular favour" (Till 2009). All these activities can contribute to US soft power capital. During port calls, deployed sailors frequently help communities on land. Examples include volunteer work such as supporting school construction and maintenance, helping to build hospitals, and inviting foreign nationals aboard a US Navy ship. While such humanitarian assistance activities are the by-product of routine port calls, humanitarian assistance operations are sometimes deployed for the sole purpose of delivering assistance. By delivering aid, the United States can demonstrate goodwill, reassure support, shape perceptions, build relations, and thus generate soft power. For example, the disaster relief aid delivered in response to the Tsunami in South-East Asia resulted in a more positive attitude toward the United States, suggesting a positive effect of this display of soft power in opposition to the traditional hard power use of military assets. After realizing the potential of health diplomacy, the United States decided to deploy the hospital ships USNS Mercy and USNS Comfort in biannual missions to countries of 
interest in the Pacific Commands (PACOM) and Southern Commands (SOUTH$\mathrm{COM}$ ) areas of responsibility (AOR). In addition to "winning hearts and minds," these missions serve as a training and relationship building opportunity for US and foreign forces and engage in capacity building for future disasters. Admiral Fallon (2007) observed that

\begin{abstract}
Our experience with the 2004 Indian Ocean tsunami relief effort revealed the tremendous influence of DoD-led humanitarian operations in reinforcing a positive view of the U.S. (...). Since then, we have adjusted our priorities and resources to achieve those effects through deliberately planned humanitarian assistance efforts. The paramount event of this type in 2006 was the deployment of the Navy hospital ship USNS Mercy. During a 5-month period, Mercy conducted ten humanitarian visits among predominantly Muslim populations in South and Southeast Asia. (...). Events of this type will continue to be central to our security cooperation in the USPACOM AOR.
\end{abstract}

These ambitions beyond improving the health of the target population make humanitarian assistance a tool for politics. This has triggered much criticism and remains controversial. Before we turn to the question of the soft power potential of hospital ship missions, we need to understand the differences between disaster relief and humanitarian assistance.

\title{
Humanitarian Assistance Versus Disaster Relief
}

Humanitarian assistance and disaster relief, although often discussed together, are two very distinct missions with different political dynamics. While many of the advantages as well as concerns apply to both operation types, they are nevertheless fundamentally different and pose specific challenges and opportunities. Humanitarian assistance missions are proactive and largely a reaction to artificial events, while disaster relief is reactive and mostly called upon after natural disasters. The latter require immediate reactions to events such as earthquakes, flooding, hurricanes, cyclones, tornadoes, tsunamis, fires, volcano eruptions, landslides, and storms. Even though warning systems are improving, natural disasters mostly strike with little to no forewarning; thus, these operations focus on emergency relief and immediate humanitarian help to alleviate the suffering with only minimal levels of preparedness. Also important is the environment in which the operations take place. Proactive humanitarian assistance missions are deployed in both permissive and nonpermissive environments, while disaster response largely occurs in a permissive environment - even when it was hostile prior to the event such as in Aceh, Indonesia before the Tsunami.

Civilian agencies, the main actors in humanitarian assistance and disaster relief, are very critical of the military's increasing involvement. Their main argument against military activities in the humanitarian arena stems from their principles of neutrality and impartiality as armed forces are directed by government policy (Chretien 2011). The presence of both civilian and military actors may blur the lines between the spheres, possibly confusing and endangering the roles of civilian aid workers. It is argued that the nature, mission, and experience of civilian agencies make them more capable of providing impartial aid and adapting to local cultures. Military forces find themselves in an operational environment and amongst humanitarian actors with whom they are unfamiliar (Daniel 2006). But often, such as immediately after a natural disaster, civilian agencies lack essential means to deliver aid. Militaries, on the other hand, are well equipped to function in a setting where infrastructure is destroyed and their capabilities in the areas of personnel, equipment, logistics, and expertise can be decisive. Military forces are trained for crisis situations; 
thus, disaster relief is a more compelling military mission because it suggests a better fit with more traditional activities. Because of the destruction accompanying natural disasters and the necessity of an immediate response, civilian actors are more likely to accept military support in this capacity and have praised the US military's response, noting that no other organization can deliver large-scale logistical capabilities and relief assets so rapidly (Chretien 2011). More controversial are the increasing humanitarian assistance missions. Under the umbrella of humanitarian assistance, the Department of Defense has engaged in various civil-military health activities, many of which would be better defined as development work according to civilian agencies (Bonventre, Hicks, and Okutani 2009). Many NGOs and other civilian actors have called for DoD to limit its engagements to last resort disaster relief (Almquist 2012; Interaction 2013).

In 2009, the Joint Chiefs of Staff released a document distinguishing between two types of military foreign assistance: foreign humanitarian assistance (FHA) and humanitarian civic assistance (HCA). FHA is tasked to tend to urgent needs in a host nation triggered by a disaster or catastrophe. HCA is funded under separate authorities and receives its authorization by Title 10, U.S.C, Section 401. By statute, HCA missions must serve the US and host nation's security interests, and the operational readiness skills of the participating armed forces must be promoted. "Assistance is limited to: (i) Medical, surgical, dental, and veterinary care provided in areas of a country that are rural or are underserved by medical, surgical, dental, and veterinary professionals, respectively, including education, training, and technical assistance related to the care provided. (ii) Construction of rudimentary surface transportation systems. (iii) Well drilling and construction of basic sanitation facilities. (iv) Rudimentary construction and repair of public facilities" (Joint Chiefs of Staff 2009). Despite this useful distinction, the general term "humanitarian assistance" is widely used to describe both types of aid. Understanding the definitions of and differences between humanitarian assistance and disaster relief is particularly important when working with different actors because their classifications are likely to be different. Proactive hospital ship missions are not initiated by an imminent disaster; thus, the term "humanitarian civic assistance" better describes these proactive missions.

\section{US Hospital Ships}

Today the USN operates two hospital ships. The USNS Comfort and the USNS Mercy are both converted San Clemente-class supertankers re-fitted into floating trauma centers. Both vessels are commanded by the US Military Sealift Command (MSC); one is maintained on each coast (Mercy is stationed in San Diego, CA, Comfort is stationed in Norfolk, VA) with a small civilian crew and an embarked core naval medical team. The ships are 894 feet long and when fully operational have 63 civilians, 956 naval hospital staff, and 258 naval support staff. Both hospital ships are equipped with a 1,000-bed hospital facility, 12 operating rooms, and a helicopter deck and side ports to take on patients at sea. This is important as many ports lack infrastructure for the docking of such large vessels, and often they have to anchor off coast. Thus, the majority of patients arrive by helicopter and a smaller number by boat.

The hospital ships' primary mission is to provide emergency medical support for US armed forces deployed in combat (Wayne 2008). Their "secondary mission is to provide full hospital services in support of US disaster relief and humanitarian missions worldwide" (United States Navy 2008). The USNS Mercy deploys biannually to the Pacific as part of the mission PACIFIC PARTNERSHIP (2006, 2008, 2010, 2012), the USNS Comfort to the Caribbean Basin and Central 
and South America in mission CONTINUING PROMISE (2007, 2009, 2011). ${ }^{3}$ Table 1 provides an overview of the USNS Mercy and USNS Comfort humanitarian assistance deployments since $2006{ }^{4}$

US Navy hospital ship missions are organized by SOUTHCOM and PACOM, respectively, but many different actors are involved in the planning phase and the mission itself. The country choice is based on a complex decision-making process and is heavily supported by the US ambassadors to the countries in the relevant region. The Department of State, and in particular USAID, and the DoD are working toward better mutual understanding and cooperation to jointly further US national interests and foreign aid objectives. Since 2011, the Navy Liaison Officer at USAID helps to facilitate coordination. While cooperation between all actors needs be improved in the future, the visits are increasingly characterized as "whole-of government interagency missions" (United States Department of Defense 2012). In 2012, USAID, the Department of Justice, the National Oceanic and Atmospheric Administration, the Army, Air Force, and the Marine Corps were all involved in PACIFIC PARTNERSHIP. As part of every mission, medical staff from foreign countries and an increasing number of NGOs join the crew. Both the US government and NGOs benefit from this collaboration. The hospital ship provides the NGOs with transportation and housing, and NGOs are often better informed about the needs of the populations, as well as local customs and traditions, and might even have worked on the ground before. However, despite this increased collaboration, civilian agencies remain critical of these missions and the support extends not much beyond the involved NGOs. Concerns such as the short-term focus and lack of integration with other HA programs remain.

Once the countries are chosen, so-called Pre-Deployment Site Survey (PDSS) teams are dispatched. The teams meet with the respective ministries of health and US embassy personnel to discuss country-specific plans. This includes surgical capability, main health concerns, special needs, and the extent of possible aftercare. The missions are not limited to treating patients aboard the ship but also include activities on shore such as training session and medical and veterinary services in remote locations. A few days before the hospital ship arrives, an Advanced Coordinating Element (ACE) team finalizes plans in country. The host countries provide documentation of the patients to be evaluated by the USNS crew, including a list of surgical patients to simplify the procedure and avoid any delays (Hartgerink et al. 2010).

While the disaster relief after the Tsunami came in the form of an aircraft carrier, hospital ships are not warships. They are white hulls with a red cross, recognized as protected platforms in whatever capacity they serve (Grunawalt 2005). Whereas the use of aircraft carriers for disaster relief shows a hard power tool in a soft power function, health diplomacy by US Navy hospital ships does not involve hard power warships. Yet hospital ships convey US military might and power. A vessel intended to serve US servicemen is operating as a facility for foreign nationals in need. A Navy capable of maintaining a hospital ship of this size is no doubt capable of large-scale operations. The size of the ship can both demonstrate a larger commitment to politicians and trigger admiration by the patients and observers. This argument also helps to underline the signaling

\footnotetext{
${ }^{3}$ As the USNS Comfort and Mercy only deploy biannually, every other year a large-deck amphibious ship, a grey hull, is sent in their place. However, in this paper, I focus only on the hospital ship missions because of their larger capacity and visibility.

${ }^{4}$ Unfortunately, CONTINUING PROMISE 2013 was canceled due to the sequestration. It remains to be seen whether there are negative consequences by not following through with the promised visits and how HA operations are valued in future budgeting.
} 


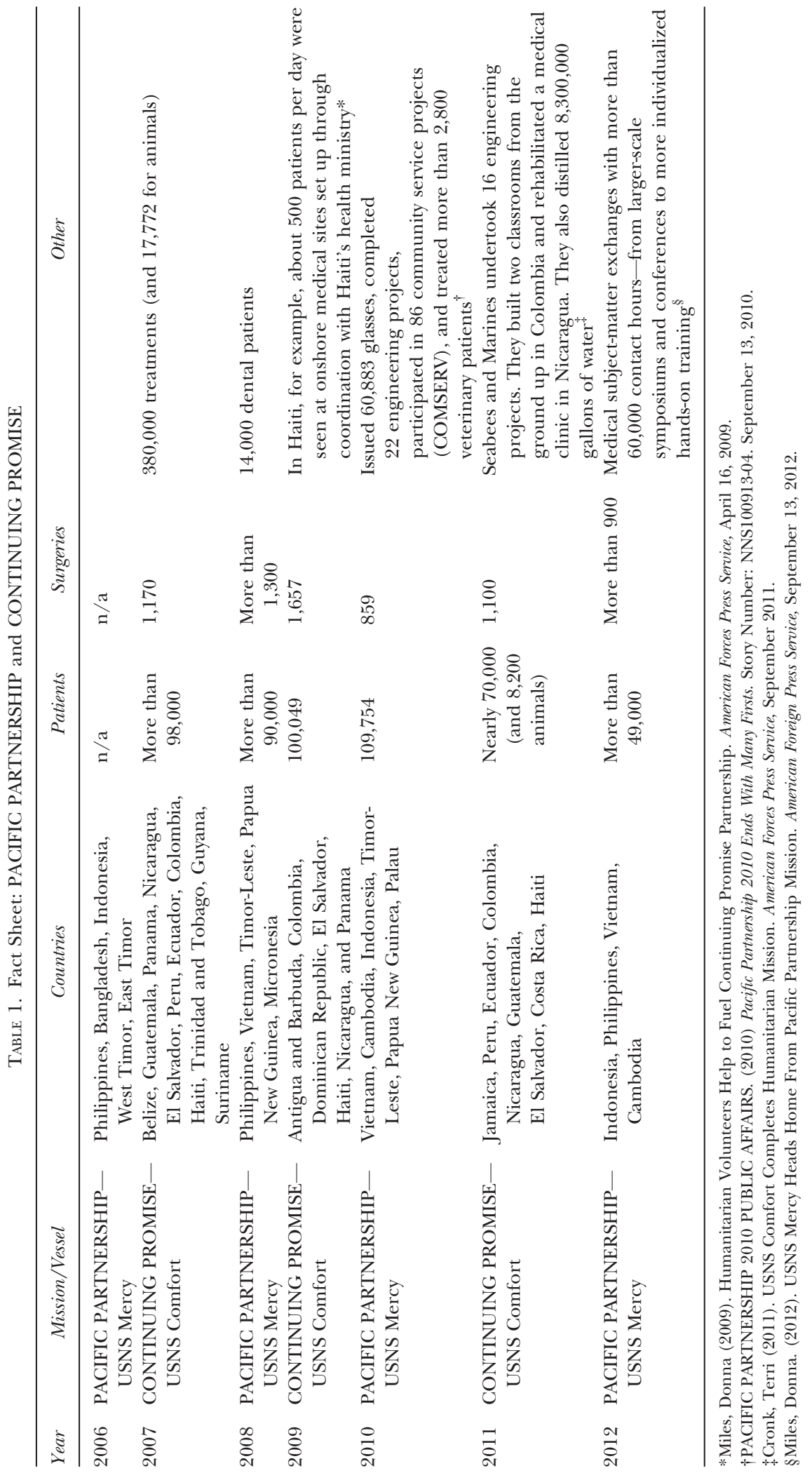




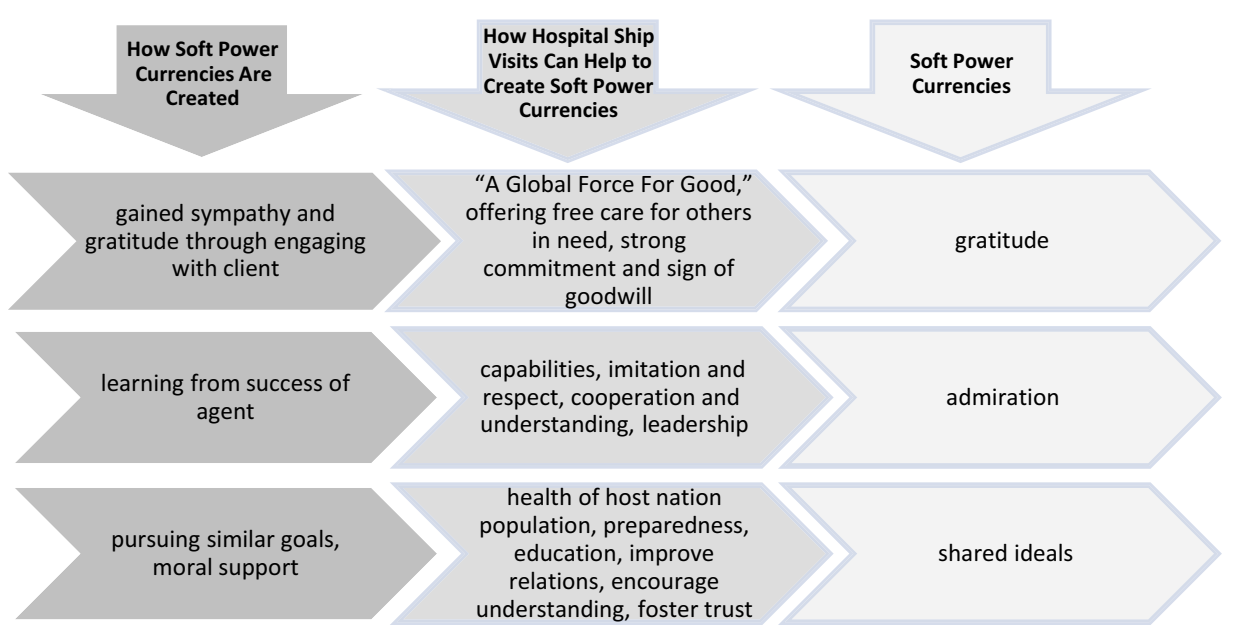

FIG. 1. Soft Power Currencies

power these large vessels convey that individual Department of State initiatives cannot provide.

\section{The Soft Power Potential of Hospital Ship Missions ${ }^{5}$}

\section{Soft Power Currencies}

There are different ways to measure the soft power potential of military humanitarian assistance. Vuving (2009) suggested replacing the question, "What constitutes soft power?" with "What generates attraction?" thereby focusing on the attraction component of the definition. He defines three power currencies that generate attraction and thus soft power: gratitude, admiration, and shared ideals, values, causes, and visions. The first form of soft power currency is created through the positive attitude of agents when engaging with the clients. Soft power is generated by gaining gratitude and sympathy. The second soft power currency is concerned with the actual work to create soft power, where the client learns from the success of the agent resulting in the power of admiration. The third soft power currency is represented by the shared ideals, values, causes, and visions of the agent. The need for moral support and the tendency to join forces with those who pursue the same goal are thought to work toward generating this currency of soft power. Thus, for this currency, the power lies in inspiring the client. These three elements can be applied to hospital ship visits to better understand their value to the United States. Figure 1 provides an overview.

The power of benignity can take many forms but mostly lies in "doing good to others." The recruiting slogan already presents the US Navy as "A Global Force For Good." The mission of hospital ship visits in particular is to do good and offer free help and care to people in need. Admiral Stavridis (2010), former commander of the US Southern Command, observed the positive influence US naval forces exerted in Latin America and the Caribbean and the capability of military humanitarian assistance to improve the image of the United States and military forces in

\footnotetext{
${ }^{5}$ The United States is not the only country to deploy military hospital ships. China has also recognized the power of health diplomacy and the soft power potential of humanitarian assistance. The first deployment of the Chinese hospital ship Peace Ark to the Gulf of Aden underscored the Chinese soft power interests in Africa (Mackenzie 2011). In November 2011, the Peace Ark departed for its most recent deployment, Operation "Harmonious Mission" to Cuba, Jamaica, Trinidad and Tobago, and Costa Rica in "America's backyard"(McFadden 2011).
} 
particular. He found that initiatives to improve health security demonstrate that the United States cares and is willing to help the people in the region, whereas counter-narcotics and terrorism activities are largely perceived as focusing on narrow US interests. As Vuving (2009:9) says, "you also appear benign when you are more harmless than your condition suggests. (...) when you behave unselfishly (...) [and] you are putting other people's interests before your own." These criteria can be met with hospital ship visits and translate into high levels of gratitude. Bonventre et al. (2009) conclude that "hospital ships' visits to Central and South America have paid dividends not only for the skills of military medics but also in influencing both populations and government leaders to view the United States and its military in a more favorable light." The presence of US NGOs and civilian actors in addition to the military can possibly help to further enhance the perceived benignity of these missions. Another important factor is the level of global attention. Hospital ship missions are planned months in advance and are not "dependent" on natural or artificial disasters and are thus less under the watch of global community. After a large natural disaster or war, the global community expects US support and aid. Hospital ship missions, however, while still helping people in need, seldom make a difference between life and death. Because only limited attention is paid to these visits, it can be argued that the level of goodwill is even higher because the United States is less likely to receive any of the benefits from the positive global recognition generally associated with disaster response. Yet the population and government may interpret proactive humanitarian assistance as a stronger commitment and sign of goodwill.

Admiration can be triggered by a variety of attributes, among them a strong military, a wealthy economy, advanced science and technology, or success. The fact that the United States can deploy large vessels to help people in need demonstrates capability, an important indicator for the potential to elicit admiration. Similarly, only a wealthy economy can afford to undertake proactive humanitarian assistance. This show of capability and goodwill can generate admiration which is said to positively translate into imitation and respect. Vuving (2009) also argues that admiration can help to overcome suspicion and hostility and work toward cooperation and understanding. Ideally, clients would seek US advice in other matters and show respect for other US decisions by their support of them. Of course, it is difficult to determine in practice how this support should manifest itself as there are many different levels and possible venues. Activities can range from backing of small-scale US diplomatic initiatives in the host country or region to United Nations voting. Depending on the desired outcome, an increase in bilateral diplomatic activities may be enough. Imitation is even more difficult to measure, and certainly respect does not have to translate into support for US policies.

Shared ideals, values, causes, and visions are very important in international relations. Striving for a common goal is said to encourage cooperation and friendship. It builds confidence in moral authority and legitimacy of the agent. By caring for the health of the host nation's population, the US and the host nation government share a common goal. This again can translate into stronger relations and support for the United States and a more favorable attitude toward the United States overall. Ideally, cooperation during the mission translates into cooperation in other matters and shared ideals, values, causes, and visions encourage understanding and foster trust for future interactions.

\section{Hospital Ship Mission Challenges}

Hospital ship missions carry some of the risks described above. As mentioned earlier, one of the weaknesses of soft power is that it lies within the people to decide how much power it will have, and there is limited influence on how the 
actions will be perceived by the target population and host government. Because payoffs are not immediate and are rather manifested in "storing up political capital" (Nye 2004), it is difficult to attribute favorable outcomes to specific missions as results may be years away. "Nonetheless," Nye (2004) argues, "the indirect effects of attraction and a diffuse influence can make a significant difference in obtaining favorable outcomes in bargaining situations. Otherwise leaders would insist only on immediate payoffs and specific reciprocity, and we know that is not always the way they behave." The United States, Nye says (2004), effectively used soft power after the Second World War to form alliances and institutions with common goals. Gratitude, admiration, and shared ideals, values, causes, and visions all helped to forge these coalitions. These developments take time, and similarly it might take time before hospital ship missions translate into soft power. Conversely, however, it is also possible that host nations reciprocate favors immediately after the visit rather than storing up political capital resulting in only short-term influence.

The problem of perception is very relevant to humanitarian assistance. While hospital ship missions offer many opportunities to attract and persuade, the potential negative effects should not be overlooked. Problems include the limited time spent in each country, ${ }^{6}$ the resulting restricted number of patients receiving treatment, and unavailability of necessary follow-up care, which, in the worst case, may cause even bigger health problems than before. Ritchie and Mott (2003) note: "The attempts to gain the hearts and minds [through humanitarian aid] may also backfire. If Americans are perceived as treating only one clan, the other may be angry." Additionally, unrealistic expectations can trigger dissatisfaction with US efforts and consequently negatively affect public opinion. Furthermore, the population could be frustrated that the United States might not come back to the same place, and after a few days of top-level care, they have to rely on the local capacities again. Such considerations might turn the gained trust into anger. From a government's perspective, problems can arise when the population becomes dissatisfied with the current health services prompted by the high-level care during the hospital ship visits. For example, while Bonventre et al. (2009:18) found positive effects of the deployments to Central and South America, they also observed that "the Mercy's visit to Indonesia was more problematic, because the standard of care delivered far exceeded what the Indonesian government was able to provide after the ship departed, and Indonesia claimed that this had undermined its legitimacy and authority." Similarly an article in the Tico Times (Williams 2011) from Costa Rica described how many patients had voiced complaints about inattentive national hospitals. While they often have to wait for years to get appointments at the local hospital, one woman is cited saying "The gringos come here and give me a check-up in 2 days." Such considerations might reverse the positive effect of gratitude from a government's perspective.

As it is argued that soft power currencies take time to develop and even more time to translate into power, one single hospital ship visit is not likely to trigger host nation support for US policies or long-lasting positive attitudes toward the United States in the host population. Gratitude and admiration for example can still be felt but may fade after a few weeks. It may thus be important to provide a certain continuity of aid and consider a return of the hospital ship during the

\footnotetext{
${ }^{6}$ This issue was addressed in the 2012 PACIFIC PARTNERSHIP mission. Unlike in earlier years, the vessel spent almost two weeks in every port. Thus, instead of visiting as many countries as possible, the focus lay on extending each stay for as long as possible (see PACIFIC PARTNERSHIP 2012: http://www.cpf.navy.mil/pacific-partnership/ $2012 /)$.
} 
next deployment. Wilder (2010) finds that the level of US aid to Pakistan was dependent on the current importance the United States attached to the country as a strategic ally, in what he calls a "front-line state" or "forgotten state." US "aid programmes have much more to do with buying or renting influence, especially with the Pakistan military, and promoting US security interests, rather than helping Pakistanis." While his study analyzes assistance in a much broader framework, this problem nonetheless translates to hospital ship visits if countries are not revisited in subsequent years. If, however, the United States wants more immediate payoffs, continuity is not as important and "renting" current influence can be sufficient.

Up to now, the United States largely has relied on measuring efforts rather than effectiveness to evaluate hospital ship missions. Success is measured by counting the numbers of surgeries or treated patients. While these numbers are certainly important, they fail to capture the bigger picture about enduring impacts and how these missions can increase US soft power and support national security objectives. Thus, if one wants to answer the question whether in a fiscally constrained environment, military humanitarian assistance should be continued, new measures of effectiveness have to be defined and evaluated.

\section{Measures of Effectiveness}

\section{Macro-Level Influence}

In the realm of disaster response, disaster diplomacy explores whether natural disasters encourage cooperation between countries that traditionally have been enemies. The concept of disaster diplomacy is concerned with strategic and political outcomes. Possible questions include whether disaster activities triggered diplomatic activities and whether they were long-lived or abated soon after the disaster (Kelman 2006). Similarly, the questions in regard to hospital ship missions should be whether, through humanitarian assistance, cooperation is encouraged beyond the immediate aid activities and how this translates into possible benefits for the United States and/or humanitarian benefits for the partner countries. But before we can answer this question, we need to know what the United States wants to achieve with humanitarian assistance and hospital ship missions in particular. Only overarching but no clear goals have been stated, making it even more difficult to create robust measures. Broad goals mentioned by the DoD and the Navy include building relationships and trust, fostering goodwill, increasing interoperability for future disasters, demonstrating commitment to a region, to partnership, and to working toward common goals (see for example Vernon and Kingsley 2011; Miles 2012). Less often mentioned is capacity building to improve the health-care system in the countries visited (see for example Wojciechowski 2011).

A recent study by the Center for Strategic International Studies (Roughead et al. 2013) comes to a similar conclusion. The authors recommend "sharpen [ing] and clarify[ing] the rationale for humanitarian engagement." The study evaluates the PACIFIC PARTNERSHIP 2012 operation, based on interviews within the Pacific Command, the Pacific Fleet, US country teams, and foreign sources in Vietnam such as officials in the ministry of health, defense, and foreign affairs and local officials. On the macro-level effectiveness, the study finds that HA missions expand US influence, improve access, and support both military and diplomatic relations with the host nations and other organizations. While these results are encouraging, more systematic research is necessary to validate these findings. 
Using a more general and quantitative approach, Major (2012) tried to create a soft power measure by comparing the UN voting behavior of nations ${ }^{7}$ after Theater Security Operations (TSC) ${ }^{8}$ with the policy preferences of the United States. Via a unidimensional parametric scaling model, estimated via a Bayesian algorithm, he creates a measure for the divergence between the preferred policies of the United States and the host nations which, in turn, is believed to measure states' "attraction" for policies favored by the United States (and thus the latter's "soft power"). He tested whether engagement led to a shift in the ideal point of the host nation that is closer to the ideal point of the US policies. His data, based on the (U)TSCMIS, the (UNCLASSIFIED) Theater Security Cooperation Information System, ${ }^{9}$ include not only hospital ship visits but also events such as International Cadet Program, Counterproliferation Awareness Training, Military Transition Assistance, Asia-Pacific Military Medicine Conference or African Attaché Roundtable. The results are generally positive. While they only show a modest effect, it nonetheless seems that these engagements "pay off" for the US military.

\section{Micro-Level Influence}

Datta (2009) finds a "statistically significant relationship between global attitude toward" the United States and political outcomes in line with US national interests. Most of the existing opinion research focuses on postdisaster relief evaluations rather than humanitarian assistance. Positive results were found in public opinion surveys conducted in Indonesia, Bangladesh, and Pakistan in 2006 (Terror Free Tomorrow 2006) and in Sri Lanka in 2005 (Rajapaksa and Dundes 2006). ${ }^{10}$ While many people in these three large Muslim nations oppose the US war on terror, they were nevertheless very grateful for the disaster relief provided by the United States and even wished for an increase in activities. The interviews revealed that after receiving aid, the popular opinion toward the United States has been clearly more favorable than before. While the increase in positive attitudes after the Tsunami relief is widely acknowledged, the influence of the earthquake relief in Pakistan in 2005 for example is more controversial. A study conducted by PEW (Wike 2012) on the impact of humanitarian aid on the image of the United States finds only a modest increase at the national level, shortly followed by a renewed decrease beginning in spring 2007. Wilder (2010) finds no positive effect on attitudes at the national level. However, a study by Andrabi and Das (2010) conducted four years postearthquake found differences between Pakistanis living in close proximity to the affected region and those living at a distance. Proximity to the fault line encouraged higher levels of trust. After controlling for other factors, the two researchers attribute this to the greater exposure to "Western humanitarian aid organizations" after the earthquake. The results are thus mixed: While some are very promising, others offer a less optimistic perspective.

\footnotetext{
${ }^{7}$ Other research is concerned with the impact of US foreign aid on UN voting behavior (see for example Wang 1999).

${ }^{8}$ TSC describes all US military efforts to build relationships, improve friends' and allies' capabilities, and provide the United States with peacetime and contingency access to prevent future conflict through shaping of the environment.

${ }^{9}$ The TSCMIS database (1998-) captures the operations of each Unified Combatant Command (COCOM). Because each command is responsible for entering the data, the reports vary greatly. Unfortunately, we have to assume that many operations are missing, but these data present the best available collection up to date.

${ }^{10}$ Indonesia, Bangladesh, and Sri Lanka received US disaster response for the Tsunami in December 2004, Pakistan for the large earthquake in 2005.
} 
One example for the impact of humanitarian assistance is the US stability operations in Afghanistan. Winning hearts and minds as part of the US counterinsurgency strategy has largely been regarded as a failure and triggered much criticism, in particular from the aid community (Williamson 2011). A recent assessment found only minor short-term improvements after aid projects and only little evidence for winning people over, away from the insurgency (Chretien 2011). On the contrary, an earlier study found the Taliban's own hearts and minds campaign to be quite successful (Senlis Council 2006). Of course, it is difficult to compare effects of aid in different situations such as disaster relief and humanitarian assistance and whether aid was delivered in a permissive or nonpermissive environment. Furthermore, the PEW study (Wike 2012) concludes that significant effects on public attitudes are more likely when there already is "a reservoir of goodwill toward the United States." In countries with very negative attitudes, humanitarian assistance is less likely to have an impact.

\section{The Way Ahead}

US ambitions for military humanitarian assistance are manifold. While the previous section focused on people's attitudes and governmental relations, the success of health-care, veterinary, and construction projects are important US objectives for building relationships and trust, fostering goodwill and working toward common goals. The success of US activities is relevant as it impacts the level of soft power currencies. Long-lasting positive effects are likely to increase the level of gratitude, admiration, and shared values, resulting in stronger soft power influence. The following are possible approaches to develop measures of effectiveness to be able to identify change. Based on these indicators, more complex models can be created to establish a causal connection and assess soft power capital.

1. Host nation health-care capacity building

a. Develop indicators to assess long-term improvement

b. Post-visit interviews to follow up on long-term success and sustainability of projects

2. Military-to-military relations

a. Define improved relations and enhanced interoperability

b. Develop indicators to measure improved relations and interoperability

3. Population and government and local officials

a. Develop indicators to measure diplomatic and political success

b. Post-visit interviews: Assess whether missions had an impact on attitudes toward the United States, whether they resulted in gratitude, admiration, or shared values

c. Track newspaper coverage in the relevant regions and United States and evaluate the framing, tone, and salience of certain aspects

\section{Host Nation Health-Care Capacity Building}

While immediate treatments are more likely to positively affect the attitudes toward the United States, capacity building offers long-term improvement for 
the health-care services and infrastructure of a country and is thus more likely to result in lasting gratitude by the host nation government and generate soft power in the form of political capital. In the most recent hospital ship missions, an increasing number of activities have focused on capacity building rather than immediate treatments. Capacity building cannot be simply accounted for with measures of effort such as the number of surgeries. During CONTINUING PROMISE 2011, for example, host nation medical practitioners were invited aboard the USNS Comfort to receive training in assessing a baby's health right after birth and to learn how to react to breathing problems (Richardson 2011). One way to evaluate the effectiveness rather than the effort would be to follow up and ask whether the practitioners were able to put their learned skill to use or even share their experience with other providers. Similarly, conducting a hygiene promotion workshop in a rural community is just a first step. Only follow-ups can monitor whether washing hands, for example, was continued after the team has left. Possible follow-up partners include other USG agencies, relevant persons from the host nation, UN agencies, and NGOs (Haims, Moore, Green, and Clapp-Wincek 2011). For every activity, two different sets of indicators should be developed and monitored. The first set of measures control for the effort: the successful completion of the tasks. Several months later, the second set of measures control for the effectiveness.

Post-mission interviews are also necessary to understand whether the mission was successful in providing the people with what they need. An OECD (1999) evaluation of development programs states that

\begin{abstract}
interviews with a sample of the affected population should be a mandatory part of any humanitarian assistance evaluation. (...) Even where time and the situation permits, humanitarian agencies are often poor at consulting or involving members of the affected population and beneficiaries of their assistance. Consequently, there can often be considerable discrepancy between the agency's perception of its performance and the perceptions of the affected population and beneficiaries. Experience shows that interviews with beneficiaries can be one of the richest sources of information in evaluations of humanitarian assistance.
\end{abstract}

Delivering the right assistance will positively affect the level of gratitude, admiration, and perception of shared values and thus provide more soft power capital.

\title{
Military-to-Military Relations
}

Another overall goal is to improve the relationships between militaries and to enhance their interoperability. It is important to establish more specific goals and guidelines. If the goal of improving relations can be met with an increase in cooperation, one possible indicator is the number of Theater Security Cooperation activities. The following graph shows the increase in TSC exercises between the United States and countries visited by USNS Mercy (Figure 2).

Of course with these data alone, attribution is not possible, but many countries show a stark increase since 2006. All countries with the exception of Palau and Papua New Guinea more than doubled their joint TSCs since 2003. The often-mentioned host nation capacity for disaster relief is more difficult to assess, and only a real crisis can put improvements to the test. In the meantime, one possible measure is to define relevant indicators and quantify progress in disaster preparedness and response mechanisms after future joint training sessions. Examples include quantifying the level of readiness through metrics such as the establishment of guidelines defining responsibilities, provisionary shelters, clean water access, food supplies, and interaction procedures with third countries. 


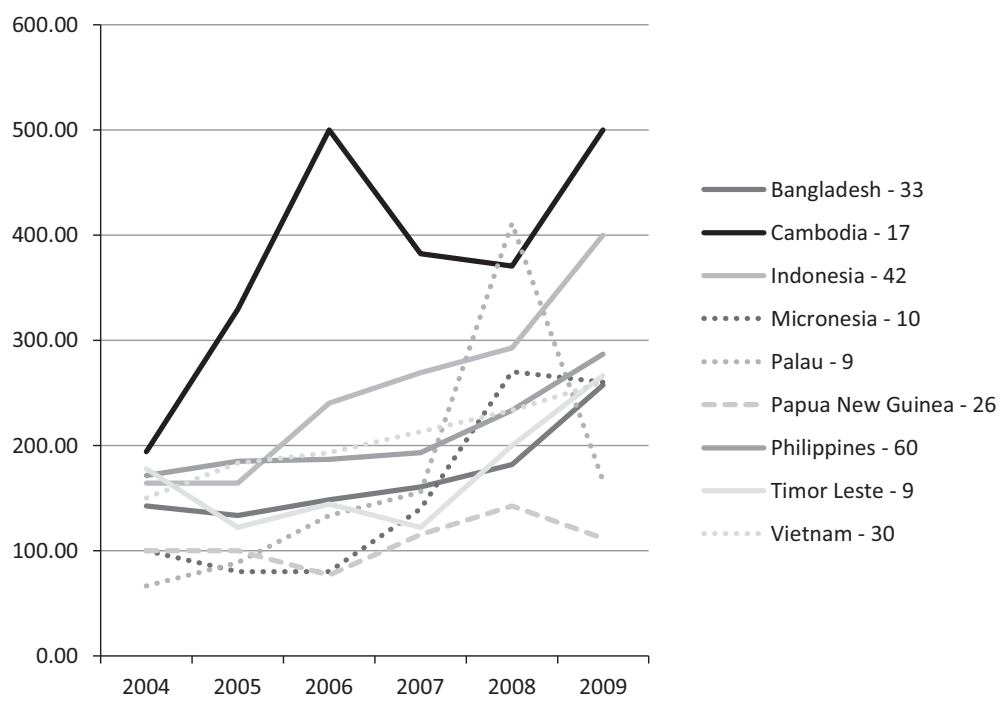

FIG. 2. Increases in Theater Security Operations with Partner Countries in Asia-Pacific in Percent, 2004-2009 (the numbers next to the country names show the starting point of TSC exercises in 2003)

\section{Population and Government and Local Officials}

The measurement of the soft power currencies gratitude, admiration, and shared values requires various indicators. As mentioned previously, the challenges to evaluate success include long-term ambition, intangible concepts such as trust or improved relationships, as well as the problem of attributing change to a particular activity. Possible indicators on a governmental level include bilateral agreements and amendments (Ganapati, Kelman, and Koukis 2010), voting behavior (Major 2012), ambassador activity, and exchange with the ministries of health. As US ambassadors play important roles in the missions, an increase in invitations to meetings and events by the host nation government could serve as one indicator for closer relations. Similarly, lasting relationships can be assessed by monitoring the exchange between US government agencies and the host nations' ministries of health following the close collaboration before and during the missions. A recent project by the University of Texas (Matwiczak 2010) released different metrics to assess the impact of public diplomacy. Some of them could be modified and applied to military HA:

1. Relative change in the number of US policy-related informational events directed toward foreign governments in a fiscal year (FY)

2. Relative change in number of government officials who participate in government exchange programs in a FY from the previous FY

3. The number of statements (official statements, editorials, interviews, or blogs) released by government officials in a FY that correctly characterize US military humanitarian assistance

4. Relative change in the number of elites who attend policy-related (military humanitarian assistance) events from the number of elites who attend similar policy-related (military humanitarian assistance) events the previous FY

5. Relative change in number of press briefs on US military assistance released by the embassy from the previous year 


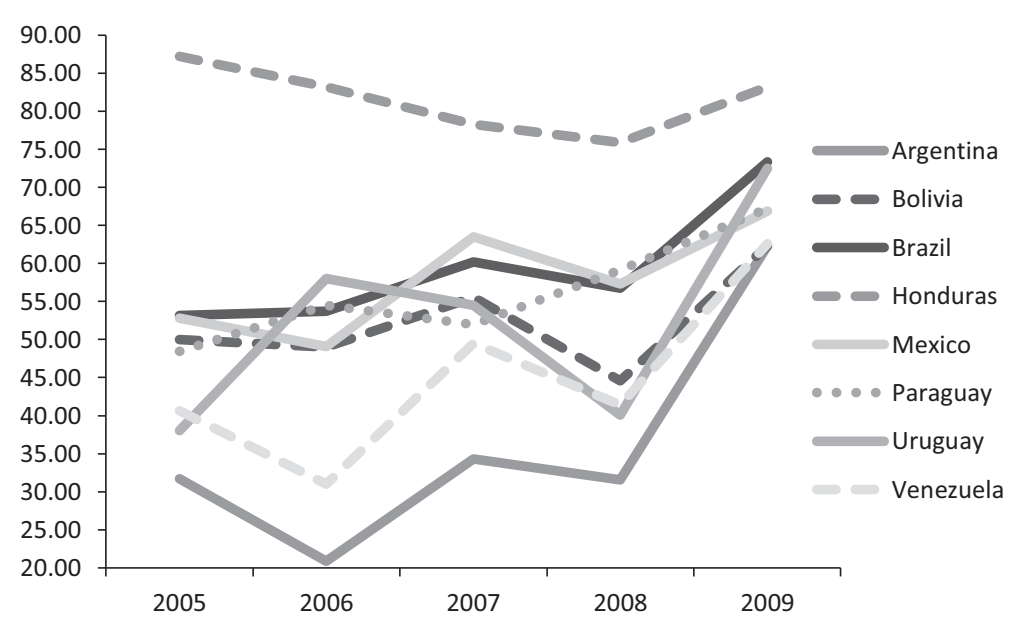

FIG. 3. Countries Not Visited During CONTINUING PROMISE Missions

6. Relative change in attendance at US-conducted policy briefings by host-country "elites"

7. Relative change in "favorable" interviews of host-country elites about US foreign policy

8. Relative change in the number of times a foreign government agrees to assist in enforcing US preferred security issues with a third party state, after a hospital ship visit

9. Relative change from previous year in exchanges between host nation and US military for purposes of training, development, and information sharing

10. The percentage of "man-on-the-street" interviews with favorable views of US policy minus the percentage from the previous FY, divided by the previous FY

The last question brings us to public opinion polls. While the PEW Global Attitudes Project either does not include the relevant countries or time frame for the USNS Comfort and USNS Mercy visits, the Latinobarómetro ${ }^{11}$ offers an alternative. Between 1,000 and 1,200 interviews are conducted annually in Argentina, Bolivia, Brazil, Colombia, Costa Rica, Chile, Ecuador, El Salvador, Guatemala, Honduras, Mexico, Nicaragua, Panama, Paraguay, Peru, Uruguay, Venezuela, and the Dominican Republic. Figures 3 and 4 compare the percentage of respondents who viewed the United States favorably from 2005 to 2009.

The countries visited by CONTINUING PROMISE with the addition of Honduras already started with a higher level of favorable opinion toward the United States. Like the PEW study by Wike (2012) suggested, it is easier to influence people who already start out with a less negative attitude. This initial goodwill might make a further increase more likely. However, to make any assumptions about the impact of US military HA on opinions, future research should control for the respondents' knowledge about the missions and whether they were personally affected. Post-visit interviews with both people who were affected (such as patients and their families, medical personnel receiving training, officials of the ministries of health) and those who only heard about the visits can help to

\footnotetext{
${ }^{11}$ The Latinobarómetro is published annually since 1995. The public opinion surveys are conducted in 18 Latin American countries and represent more than 400 million inhabitants. See: http://www.latinobarometro.org/latino/ latinobarometro.jsp
} 


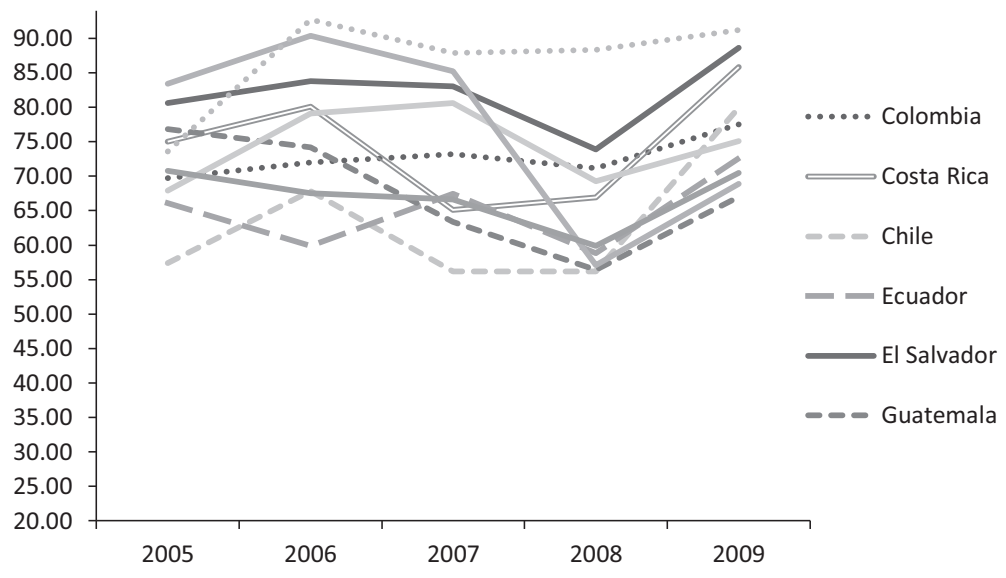

FIG. 4. Countries Visited During CONTINUING PROMISE Missions

quantify the impact of the military humanitarian assistance on attitudes toward the United States. It would be interesting to control for the possible differences between aid received by involved NGOs versus military actors. Furthermore, Andrabi and Das (2010) found proximity to aid services to be relevant for changes in attitudes.

Another promising way to communicate US soft power efforts and to understand attitudes is media coverage. Traditionally, breaking news, large number of casualties, and saving the lives of innocents receive broad media coverage (Moeller 2008). Hospital ship missions are not "news," and they are not as exciting as large-scale natural disasters and thus are less likely to make it to the front page of a newspaper. Important aspects of media impact include the density of coverage, type of coverage (success stories, neutral descriptive), and framing of the story. In the political discourse, the tone of a text may matter as much as the substantive content. Numerous studies have analyzed the tone or sentiment of text (Young and Soroka 2012). The framing of newspaper articles by highlighting particular elements, repeating or avoiding certain aspects, and using a particular language can heavily impact people's perceptions (Chong and Druckman 2007). The reader's viewpoints are shaped by the media's interpretation of events, the explanation of problems, and the casting of moral judgments (Entman 1993; Shah, Watts, Domke, and Fan 2002). Framing differs from agenda setting because it focuses on the salience or weight assigned to certain aspects of the topic, not salience of the topic itself (Scheufele 2000). Before journalists can frame their stories, agenda setting determines the emphasis a certain topic will receive. The impact of agenda setting was first discussed by Mccombs and Shaw (1972). Their study found a strong correlation between prominence of a topic in the media and the importance attributed to this topic by the audience.

One aspect of media coverage research should look at US sources. As part of communicating the US goodwill, newspaper articles can offer an important contribution to how missions are perceived. Although soft power depends on the receiver, the sender can try to maximize the potential impact. Searching LexisNexis for hospital ship coverage in major English newspapers shows that neither the New York Times nor Washington Post covered the topic. The New York Times features a total of two articles on US relations with Latin and South America that mention President Bush's announcement of the first CONTINUING PROMISE visit in 2007. The Washington Post featured five articles discussing Bush's engagement in the Western Hemisphere and one article discussing the US troop 
withdrawal from Iraq and Afghanistan in which the USNS Comforts 2011 visits were mentioned in one sentence. The only other time since 2006 that a US hospital ship received coverage was for the US disaster relief mission after the Haiti earthquake in 2010, underlining the argument that disaster relief is more exciting. This low coverage is surprising and raises questions about its perceived importance in Washington.

The other aspect of media coverage is agenda setting and framing in foreign newspapers. In other parts of the world, the most recent mission PACIFIC PARTNERSHIP 2012, for example, received more attention. The Chinese People's Daily writes on April 17, 2012, "the U.S. Navy is sending the USNS Mercy, one of its two medical ships, on a goodwill mission to Southeast Asia next month, seeking to build partnership with regional militaries. (....) The United States is focusing its military resources to the Asia Pacific region in face of budget cuts, and the Pentagon has made missions in this area a priority." The very first sentence focuses on the US collaboration with other militaries, rather than on providing aid to the local population. The article does mention the free care but together with the last sentence it highlights the increased US interest in military relations in the region; thus, the article frames the mission more as a show of military capability and less as a purely humanitarian endeavor. An article in the Indonesian Manila Bulletin from June 30 praised capabilities: "During the event, the PP12 even managed to save the life of a man who only had less than 50 percent chance of survival when he was given surgery aboard the hospital ship, USS Mercy." Another article in the Philippines Sun Star from July 4 reads, "Unity, peace, friendship and sharing of culture were the lessons learned from the 14-week medical mission and more than 3 months of civic works in the two provinces in the island of Samar." Similar statements can be found for CONTINUING PROMISE. An online newspaper in El Salvador interviewed one of the patients quoting his gratitude for the attention he received and his praise for the crew as "good people" (Elsalvador.com 2011). The same newspaper quotes another patient, describing how the crew offers more than just medical services but also "kindness and solidarity" (Zelaya 2011). A systematic examination of all media sources including Twitter and blogs would allow creating a data set in which the contents of missions' coverage could be analyzed. There are many different types of content analyses. A more simple automated approach can look at the frequency of relevant words such as "goodwill," "help," "friendship," and "gratitude," while more complicated assessments can identify the use of different frames.

\section{Conclusion}

My goal has been to position hospital ship missions in the context of soft power and to suggest how future studies could assess the effectiveness of these missions. Hospital ship visits are a good tool for signaling that the United States cares about the well-being of people in need and attaches importance to the forging of partnerships. Such operations have the power to influence both the population and governments and offer soft power benefits to the United States in addition to providing medical aid to people in need. Captain Morgan (quoted in Miles 2012), the commanding officer of PACIFIC PARTNERSHIP 2012, summarizes the value of the mission: "It demonstrates a commitment to the region, a commitment to partnership-building, and a commitment to working together toward common goals." Given the increasing importance of global health, this is a timely approach to advance cooperation and security. However, to date we do not have the data to back such statements up with evidence. In theory, these visits offer the possibility to increase US soft power capital with the help of the currencies of gratitude, admiration and shared ideals, values, causes, and visions. 
I offered some suggestions as to how mission success could be evaluated more systematically with more robust measures. In light of the tight budget for the coming years, the future of such missions is uncertain when war- and peacetime activities have to compete against each other (Freedberg 2012). A narrow perspective on naval tasks can argue that the Navy's primary mission is to fight and win wars (Carr 2010). More empirical research on the impact of military humanitarian assistance, as outlined in this paper, is necessary to convince policymakers that, given today's fiscal constraints, the limited national resources available are or are not well spent on such missions.

\section{References}

Almquist, Kate. (2012) Africa Doesn't Need the Pentagon's Charity-Why I'm Grumpy About DOD's Development Programs in Africa [Blog Post]. Center for Global Development, Rethinking Foreign Assistance Blog. Available at http://blogs.cgdev.org/mca-monitor/2012/08/africa-doesnt-needthe-pentagons-charity-why-im-grumpy-about-dods-development-programs-in-africa.php (Accessed February 20, 2013).

Andrabi, Tahir R. S., and Jishnu Das. (2010) In Aid We Trust. Hearts and Minds and the Pakistan Earthquake of 2005. Washington, DC: World Bank.

Bonventre, Eugene, Katherine Hicks, and Stacy M. Okutani. (2009) U.S. National Security and Global Health: An Analysis of Global Health Engagement by the U.S. Department of Defense. A Report of the CSIS Global Health Policy Center-Working Draft. Available at http://csis.org/files/ publication/090421_Bonventre_USNationalSecurity_Rev.pdf (Accessed January 11, 2012).

Booth, Ken. (1985) Law, Force and Diplomacy at Sea. Boston: Allen and Unwin.

Carr, Robert. (2010) The Mission Is Warfighting, Not Relief. Naval Institute Proceedings 136: 294-304.

Chong, Denis, and James Druckman. (2007) Framing Theory. Annual Review of Political Science 10: 103126.

Chretien, Jean P. (2011) U.S. Military Global Health Engagement Since 9/11. Global Health Governance IV. Available at http://blogs.shu.edu/ghg/files/2011/11/Jean-Paul-Chretien_USMilitary-Global-Health-Engagement-since-9-11_Spring-2011.pdf (Accessed December 15, 2011).

Cobble, Eugene, Hank Gaffney, and Dmitri Gorenburg. (2005) For the Record: All U.S. Forces Responses to Situations, 1970-2000 (With Additions Covering 2000-2003). Alexandria, VA: Center for Naval Analyses.

Dahl, Robert. (1961) Who Governs? Democracy and Power in an American City. New Haven, CT: Yale University Press.

Daniel, James. (2006) Operation Unified Assistance: Tsunami Transitions. Military Review 86: 50-53.

Datta, Monti N. (2009) The Decline of America's Soft Power in the United Nations. International Studies Perspectives 10 (3): 265-284.

Davidson, Вов. (2009) Modern Naval Diplomacy: A Practitioner's View. Journal of Military and Strategic Studies 11: 1-47.

Elsalvador.com. (2011) Atención de Primera en el Hospital Flotante, July 21, 2011. Available at http:// www.elsalvador.com/mwedh/nota/nota_completa.asp?idCat=6364\&idArt=6030498 (Accessed March 23, 2013).

Entman, Robert. (1993) Framing: Toward Clarification of a Fractured Paradigm. Journal of Communication 43: 51-58.

Fallon, William. (2007) Statement Before the House Armed Services Committee on U.S. Pacific Command Posture, March 7.

Feste, Karen. (2003) Intervention. Shaping the Global Order. Westport, CT; London: Praeger.

Freedberg JR, Syndey. (2012) Former CNO, DepSecDef Fight to Stop Cuts to Navy's Humanitarian Mission. AOL Defense, June 4, 2012.

Ganapati, Emel, Ilan Kelman, and Theodore Koukis. (2010) Analyzing Greek-Turkish Disaster-Related Cooperation: A Disaster Diplomacy Perspective. Cooperation and Conflict 45: 162-185.

Ghosh, P. K. (2001) Revisiting Gunboat Diplomacy: An Instrument of Threat or Use of Limited Naval Force. Strategic Analysis 24: 2005-2017.

Gray, Colin. (2011) Hard Power and Soft Power: The Utility of Military Force as an Instrument of Policy in the 21st Century. Carlisle, PA: Strategic Studies Institute, U.S. Army War College.

Grunawalt, Richard. (2005) Hospital Ships in the War on Terror Sanctuaries or Targets? Naval War College Review 58: 89-119. 
Haims, Marla, Melinda Moore, Harold Green, and Cynthia Clapp-Wincek. (2011) Developing a Prototype Handbook for Monitoring and Evaluating. Department of Defense Humanitarian Assistance Projects. RAND Center for Military Health Policy Research. Available at http://www.rand.org/content/ dam/rand/pubs/technical_reports/2011/RAND_TR784.pdf (Accessed March 31, 2013).

Hartgerink, Bradley, louisa E. Chapman, John Stevenson, Timothy F. Donahue, and Claire Pagiara. (2010) Utilization of Surgical Resources During the USNS COMFORT Humanitarian Mission to the Americas. Military Medicine 175: 638-646.

Interaction. (2013) The U.S. Military's Expanding Role in Foreign Assistance. Policy Brief. Available at http://www.interaction.org/files/FABB\%202013_Sec16_NGOAndMilitaryRelations.pdf (Accessed March 25, 2013).

Joffe, Joseph. (2006) The Way We Live Now. The Perils of Soft Power. New York Times Magazine. Available at http://www.nytimes.com/2006/05/14/magazine/14wwln_lede.html?_r=1\&pagewanted= print\&oref=slogin (Accessed May 23, 2011).

Joint Chiefs of Staff. (2009) Foreign Humanitarian Assistance. Joint Publication 3-29. Available at http://www.fas.org/irp/doddir/dod/jp3-29.pdf (Accessed October 31, 2011).

Kelman, Ilan. (2006) Acting on Disaster Diplomacy. Journal of International Affairs 59: 215-241.

Le Mière, Christian. (2011) The Return of Gunboat Diplomacy. Survival 53: 53-68.

Mackenzie, Peter. (2011) Red Crosses, Blue Water: Hospital Ships and China's Expanding Naval Presence. Alexandria, VA: Center for Naval Analyses.

Major, Solomon. (2012) Buying Your Friends? Measuring American Military Soft Power \& Recipient Country Policy Preferences. Paper prepared for the American Political Science Association Annual Meeting, New Orleans, LA, 2012.

Matwiczak, Kenneth. (2010). Public Diplomacy. Model for the Assessment of Performance. A Report to the U.S. Advisory Commission on Public Diplomacy by the LBJ School of Public Affairs, University of Texas at Austin. Available at http://www.state.gov/documents/organization/ 149966.pdf (Accessed April 8, 2013).

Mccombs, Maxwell, and Donal Shaw. (1972) The Agenda-Setting Function of Mass Media. Public Opinion Quarterly 36: 176-187.

McFadden, David. (2011) Chinese Navy Brings Medical Aid to Jamaica. The Guardian, November 1.

Miles, Donna. (2012) USNS Mercy Heads Home from Humanitarian Mission. US Defense News, September 13.

Moeller, Susan. (2008) Considering the Media's Framing and Agenda-Setting Roles in States' Responsiveness to Natural Crises and Disasters. Paper 2.1 in The Role of the News Media in the Governance Reform Agenda, co-sponsored by the CommGAP Program at the World Bank and the Joan Shorenstein Center on the Press, Politics and Public Policy at Harvard Kennedy School. Available at http://www.hks.harvard.edu/fs/pnorris/Conference/Conference\%20papers/Moeller. pdf (Accessed April 7, 2012).

Nailor, Peter. (1984) A New Environment for Navies? In Maritime Strategy in the Nuclear Age, edited by Geoffrey Till. New York: St. Martin's.

Nye, Joseph. (1990) Bound to Lead: The Changing Nature of American Power. New York: Basic Books.

Nye, Joseph. (2004) Soft Power: The Means to Success in World Politics. New York: Public Affairs.

Nye, Joseph. (2011) The Future of Power. New York: Public Affairs.

OECD. (1999) Guidance for Evaluating Humanitarian Assistance in Complex Emergencies. Evaluation and Effectiveness I. Development Assistance Committee. Available at http://www.oecd.org/ development/evaluation/2667294.pdf (Accessed January 30, 2013).

Rajapaksa, Sushama, and Lauren Dundes. (2006) Can Humanitarianism Instill Good Will? American Tsunami Aid and Sri Lankan Reactions. International Studies Perspectives 7: 231-238.

Richardson, Courtney. (2011) "Helping Babies Breathe" Training Aboard Comfort. Continuing Promise 2011 Public Affairs, April 20, 2011. Available at http://www.norfolknavyflagship.com/ news/health_fitness/article_a33e6f34-6b82-11e0-955c-001cc4c002e0.html (Accessed April 1, 2013).

Ritchie, Elspeth, and Robert Mott. (2003) Military Humanitarian Assistance: The Pitfalls and Promise of Good Intentions. In Military Medical Ethics, edited by Thomas Beam and Linette Sparacino. Falls Church, VA: Office of the Surgeon General, United States Army.

Roughead, Gary, Stephen Morrison, Thomas Cullison, and Seth Gannon. (2013) U.S. Navy Humanitarian Assistance in an Era of Austerity. A Report of the CSIS Global Health Policy Center. Washington, DC: Center for Strategic International Studies (CSIS).

Sanders, Deborah. (2007) U.S. Naval Diplomacy in the Black Sea: Sending Mixed Messages. Naval War College Review 60: 61-72. 
Scheufele Dietram. (2000) Agenda-Setting, Priming, and Framing Revisited: Another Look at Cognitive Effects of Political Communication. Mass Communications E Society 3: 297-316.

Senuis Council. (2006) An Assessment of the Hearts and Minds Campaign in Southern Afghanistan: Zroona Aw Zehnoona. London: MF Publishing Ltd.

Shah, Dhavan, Mark Watts, David Domke, and David Fan. (2002) News Framing and Cueing of Issue Regimes. Explaining Clinton's Public Approval in Spite of Scandal. Public Opinion Quarterly 66: 339-370.

Stavridis, James. (2010) Partnership for the Americas: Western Hemisphere Strategy and U.S. Southern Command. Washington, DC: National Defense University Press.

Stocker, Jeremy. (1998) Nonintervention: Limited Operations in the Littoral Environment. Naval War College Review 51: 42-62.

Terror Free Tomorrow. (2006) Humanitarian Assistance Key to Favorable Public Opinion in World's Three Most Populous. Muslim Countries Results from New Polls of Indonesia, Bangladesh and Pakistan. Available at http://www.terrorfreetomorrow.org/upimagestft/Indonesia\%20Bangladesh\%20TFT \%20Final\%20Poll\%20Report.pdf (Accessed April 8, 2009).

Thompson, Tommy. (2004) Advocating for Medical Diplomacy: A Conversation with Tommy G. Thompson. Health Aff (Millwood) Suppl Web Exclusives. W4-262-268.

Till, Geoffrey. (2009) Seapower. A Guide for the Twenty-First Century. London, New York: Routledge.

Turner, Stansfield. (1974) Missions of the U.S. Navy. Naval War College Review 26: 2-17.

United States. (2010) National Security Strategy. Washington, DC: White House. Available at http://www.whitehouse.gov/sites/default/files/rss_viewer/national_security_strategy.pdf (Accessed November 2, 2011).

United States Department of Defense. (2010) Quadrennial Defense Report. Available at http://www. defense.gov/qdr/images/QDR_as_of_12Feb10_1000.pdf (Accessed November 20, 2011).

United States Department of Defense. (2012) DOD News Briefing with Capt. James Morgan and Capt. Jonathan Olmstead, April 17, 2012. Available at http://www.defense.gov/transcripts/transcript. aspx?transcriptid=5015 (Accessed January 30, 2013).

United States Navy. (2008) Factsheet: USNS Comfort (T-AH 20). Hospital Ship. Available at http://www. msc.navy.mil/comfort/USNSComfortFactSheetAug08.pdf (Accessed May 3, 2012).

United States Navy. (2010) Naval Operations Concept 2010. Implementing the Maritime Strategy. Washington, DC: United States Department of the Navy. Available at http://www.navy.mil/ maritime/noc/NOC2010.pdf (Accessed March 14, 2012).

United States Navy, Marine Corps and Coast Guard. (2007) A Cooperative Strategy for 21st Century Seapower. Washington, DC: United States Department of the Navy.

Vernon, Alison, And M Kingsley. (2011) Assessments of Sea-Shaping Operations. Alexandria, VA: Center for Naval Analysis.

Vuving, Alexander. (2009) How Soft Power Works. Paper Presented at the Panel "Soft Power and Smart Power," American Political Science Association Annual Meeting, Toronto, September 3, 2009.

WANG, TE-YU. (1999) U.S. Foreign Aid and UN Voting: An Analysis of Important Issues. International Studies Quarterly 43: 199-210.

Wike, Richard. (2012) Does Humanitarian Aid Improve America's Image?. Pew Global Attitudes Project. Available at: http://www.pewglobal.org/2012/03/06/does-humanitarian-aid-improve-americas-image/ (Accessed September 13, 2012).

Wilder, Andrew. (2010) Aid and Stability in Pakistan: Lessons from the 2005 Earthquake Response. Disasters 34: S406-S426.

Williams, Adam. (2011) U.S. Floating Hospital Docks in Costa Rica. Tico Times, August 9. Available at http://www.ticotimes.net/Current-Edition/News-Briefs/U.S.-floating-hospital-docks-in-Costa-Rica_ Tuesday-August-09-2011 (Accessed August 21, 2012).

Williamson, Jamie. (2011) Using Humanitarian Aid to "Win Hearts and Minds": A Costly Failure? International Review of the Red Cross 93: 1035-1061.

Wojciechowski, Scotт. (2011) USNS Comfort, Continuing Promise 2011 Arrive in Guatemala. Continuing Promise 2011 Public Affairs.

Young, Lori, and Stuart Soroka. (2012) Affective News: The Automated Coding of Sentiment in Political Texts. Political Communication 29: 205-231.

Zajtchuck, JoAn. (2003) Military Medicine in Humanitarian Missions. In Military Medical Ethics, edited by Thomas Beam and Linette Sparacino. Falls Church, VA: Office of the Surgeon General, United States Army.

Zelaya, Franklin. (2011) USNS COMFORT, Salud, Desarrollo Y Calor Humano. ElSalvador.com, July 22. Available at: http://www.elsalvador.com/mwedh/nota/nota_completa.asp?idCat=8613\& idArt=6029889 (Accessed March 28, 2013). 